УДК 504.03/.05 (477), DOI 10.31210/visnyk2018.02.19

(C) 2018

Славгородська Ю. В., кандидат сільськогосподарських наук

Інститут агроекології і природокористування НААН України

\title{
СУЧАСНИЙ СТАН ТА ДИНАМІКА ЗМІН ЗЕМЕЛЬНИХ РЕСУРСІВ ЦЕНТРАЛЬНОГО ЛІСОСТЕПУ УКРАЇНИ
}

\section{Рецензент - кандидат сільськогосподарських наук В. П. Новицький}

У статті розглянуто сучасний стан використання земельних ресурсів центрального Лісостепу України. Досліджено особливості структурного розподілу сільськогосподарських земельних угідь. Визначено надмірний рівень сільськогосподарської освоєності територіі, розораності території $і$ сільськогосподарських угідь. Встановлено, що структура земельних угідь екологічно розбалансована. Проаналізовано динаміку змін земельного фонду за останне десятиліття в розрізі адміністративних областей. Запропоновано заходи щодо оптимізації використання земельних ресурсів.

Ключові слова: земельні ресурси, динаміка змін земельного фонду, оптимізація агроландшафтів.

Постановка проблеми. Земельні ресурси є стратегічною складовою природокористування будь-якої країни світу, в тому числі й України. Інтенсивність використання пов'язують 3 їх універсальністю. Земельні ресурси необхідні для багатьох видів господарської діяльності, зокрема це територіальний базис, на якому розміщуються виробничі об'єкти, інженерні споруди, комунікації для таких галузей господарства як промисловість, будівництво, сухопутний транспорт тощо. Проте особливу роль земельні ресурси відіграють у сільському та лісовому господарстві, оскільки земля одночасно виступає і територіальним ресурсом, і засобом виробництва [3].

Наразі пріоритетними завданнями у сфері використання земельних ресурсів $є$ їх збереження, раціональне використання та відтворення. Тому актуальним $\epsilon$ подальше вивчення стану використання земельних ресурсів, зокрема центрального Лісостепу України, оскільки території властива висока інтенсивність експлуатації земельних ресурсів, що зумовлена сприятливістю природнокліматичних умов, високим рівнем антропогенного навантаження тощо.

Аналіз основних досліджень і публікацій, у яких започатковано розв'язання проблеми. Проблемам ефективного використання земельно-ресурсного потенціалу приділяється значна увага вітчизняних та зарубіжних науковців.

Дослідження наукових основ землекористу- вання $з$ позицій економіко-екологічного підходу розглядають такі вчені як С. Ю. Булигін, М. А. Голубець, Б. М. Данилишин, В. В. Лавров, В. В. Медвєдєв, В. О. Паламарчук, А. П. Стадник, О. Г. Тараріко, А. М. Третяк [7], О. І. Фурдичко [8] та інші.

Незважаючи на глибину наукових досліджень та низку розроблених заходів щодо раціонального використання земельних ресурсів $[5,6]$, ефективне землекористування у сучасних ринкових умовах господарювання залишається до кінця не вирішеною загальнодержавною проблемою, що потребує подальшого опрацювання.

Мета дослідження - проаналізувати особливості структури та динаміки змін земельного фонду центрального Лісостепу України.

Головними завданнями є: дослідити структуру земельного фонду центрального Лісостепу України; проаналізувати динаміку змін земельних ресурсів у розрізі адміністративних областей; запропонувати шляхи оптимізації структурнофункціональної організації агроландшафтів.

Матеріали і методи досліджень. Зона дослідження агроландшафтів репрезентована територією Подільської та Придніпровської височин (Правобережна частина) та Придніпровської низовини (Лівобережна частина). У адміністративному відношенні територія охоплює Вінницьку, Київську, Кіровоградську, Полтавську та Черкаську області.

Інформаційною базою для виконання поставлених завдань стали звітні матеріали Міністерства екології та природних ресурсів України у відповідних областях станом на 2005, 2015 та 2016 роки [4].

Результати досліджень. Земельний фонд центрального Лісостепу України станом на 01.01.2016 р. становить 12890,9 тис. га. Значну частину займають сільськогосподарські угіддя 9321,8 тис. га (72,3\%), ліси та лісовкриті площі 1842,63 тис. га (14,3\%), забудовані землі - 538,4 тис. га $(4,2 \%)$, води (території, що покриті поверхневими водами) - 579,5 тис. га $(4,5 \%)$, інші землі - 455,22 тис. га $(3,5 \%)$ (рис. 1$)$. 


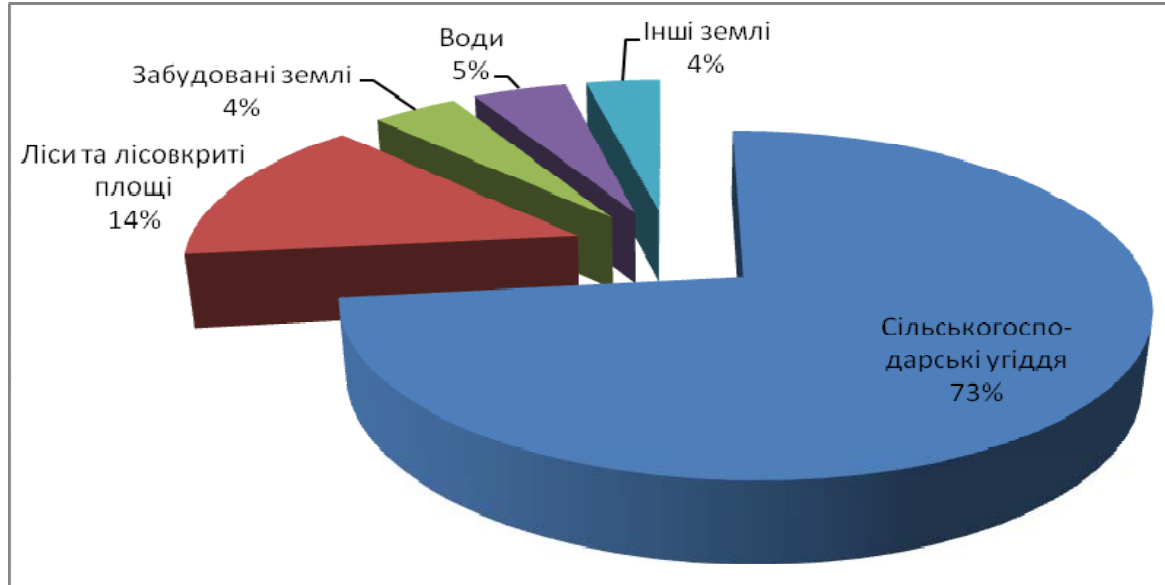

Рис. 1. Структура земельного фонду центрального Лісостепу Украӥни станом на 01.01.2016

\section{1. Динаміка змін земельного фонду центрального Лісостепу Украӥни}

\begin{tabular}{|c|l|c|c|c|c|c|}
\hline \multirow{2}{*}{$\begin{array}{c}\text { № } \\
\text { п/п }\end{array}$} & \multicolumn{1}{|c|}{ Види основних угідь } & \multirow{2}{*}{$\begin{array}{c}2005, \\
\text { тис. га }\end{array}$} & \multirow{2}{*}{$\begin{array}{c}2015, \\
\text { тис. га }\end{array}$} & \multirow{2}{*}{$\begin{array}{c}2016, \\
\text { тис. га }\end{array}$} & \multicolumn{2}{|c|}{ Динаміка } \\
\cline { 7 - 8 } & & & & тис. га & $\%$ \\
\hline 1 & Сільськогосподарські угіддя & 9418,0 & 9321,8 & 9321,8 & $-96,2$ & 0,75 \\
\hline 2 & Ліси та лісовкриті площі & 1820,9 & 1842,7 & 1842,6 & 21,7 & 0,17 \\
\hline 3 & Забудовані землі & 505,3 & 538,4 & 538,4 & 33,1 & 0,26 \\
\hline 4 & $\begin{array}{l}\text { Води (території, що покриті } \\
\text { поверхневими водами) }\end{array}$ & 578,3 & 579,6 & 579,6 & 1,3 & 0,01 \\
\hline 5 & Інші землі & 324,6 & 455,2 & 455,2 & 130,6 & 1,01 \\
\hline & Усього земель & & 12890,9 & & \\
\hline
\end{tabular}

Сільськогосподарське землекористування посідає провідне місце у сучасній структурі земельного фонду центрального Лісостепу України. Так, найнижча частка сільгоспугідь притаманна території Київської області $(58,9 \%)$, найвища Кіровоградській області (82,7%). У Полтавській області на сільськогосподарські угіддя припадає 75,3\% площі області, у Вінницькій - 76,0\%, у Черкаській області - 69,4\%.

Щодо динаміки земельних ресурсів центрального Лісостепу, то у порівнянні з 2015 роком зміни у структурі агроландшафтів незначні (табл. 1, рис. 2). Деякі зміни простежуються за період 2005-2016 рр. Так, за десятиліття площа сільськогосподарських угідь скоротилася на 96,2 тис. га $(0,75 \%)$, площа лісів збільшилася на 21,7 тис. га $(0,17 \%)$, забудованих земель - на 33,1 тис. га $(0,26 \%)$, територія, що покрита поверхневими водами, - на 1,3 тис. га $(0,01 \%)$, площа інших земель - на 30,6 тис. га $(1,01 \%)$.

Слід зазначити, що зменшення площ сільськогосподарських угідь спостерігається за всіма адміністративними областями. Найбільше скоро- чення у Вінницькій області - на 53,1 тис. га $(0,41 \%)$, далі у Київській - на 15,4 тис. га $(0,12 \%)$, Полтавській - на 15,0 тис. га $(0,12 \%)$ (зменшення за рахунок скорочення площі перелогів, а площа ріллі, навпаки, збільшилася), у Кіровоградській - на 9,0 тис. га $(0,07 \%)$, у Черкаській області - на 3,7 тис. га $(0,03 \%)$, проте площа інших земель в області збільшилася на 135,4 тис. га.

Сільськогосподарська освоєність на території центрального Лісостепу станом на 01.01.2016 коливається в межах 58,9-82,7 \%, у середньому - 72,3 \%, розораність території - 48,1-71,8 \%, у середньому $61,2 \%$, розораність сільськогосподарських угідь $81,6-87,7 \%$, у середньому $-84,6 \%$ (табл. 2). Найвищий рівень освоєності та розораності земель має Кіровоградська область, відповідно, 82,7\% та $71,8 \%$, далі Вінницька - 76,0 \% та 65,1 \%, Полтавська $-75,3 \%$ та $61,7 \%$, Черкаська $-69,4 \%$ та $60,8 \%$, Київська область - 58,9 \% та 48,1\%. Розораність сільськогосподарських угідь надзвичайно висока за усіма областями - понад $80 \%$. 


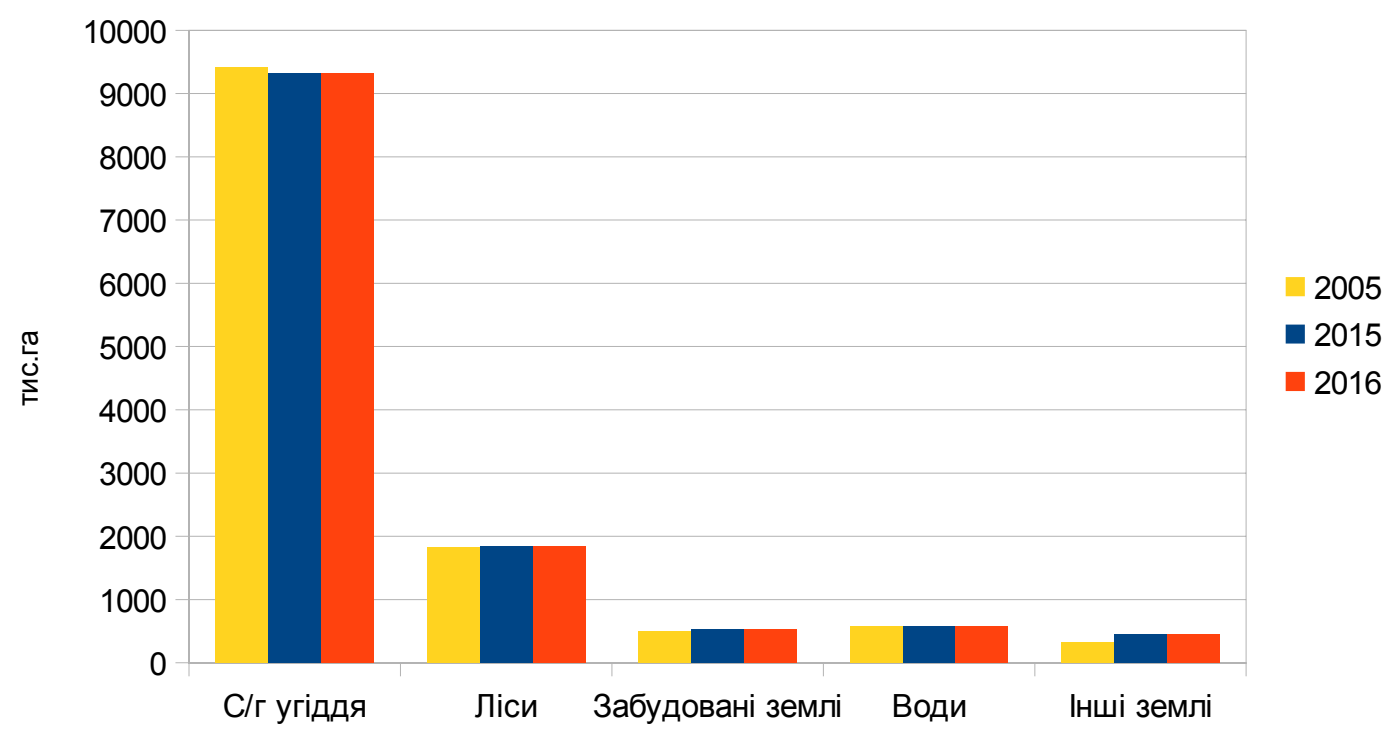

Рис. 2. Динаміка розподілу земель центрального Лісостепу Украӥни по земельних угіддях за 2005-2016 pp.

2. Сільськогосподарська освосність і розораність земель центрального Лісостепу Украӥни станом на 01.01.2016 p.

\begin{tabular}{|c|c|c|c|c|c|c|c|}
\hline \multirow{2}{*}{$\begin{array}{c}\text { № } \\
\text { п/п }\end{array}$} & \multirow{2}{*}{$\begin{array}{c}\text { Адміністративна } \\
\text { область }\end{array}$} & \multirow{2}{*}{$\begin{array}{c}\text { Загальна } \\
\text { площа, } \\
\text { тис. га }\end{array}$} & \multicolumn{2}{|c|}{$\begin{array}{l}\text { Сільськогосподар- } \\
\text { ські угіддя, тис. га }\end{array}$} & \multirow{2}{*}{$\begin{array}{l}\text { Освоєність } \\
\text { території, \% }\end{array}$} & \multirow{2}{*}{$\begin{array}{l}\text { Розораність } \\
\text { території, \% }\end{array}$} & \multirow{2}{*}{$\begin{array}{l}\text { Розораність } \\
\text { с/г угідь, \% }\end{array}$} \\
\hline & & & всього & $\begin{array}{l}\text { рілля } \\
\end{array}$ & & & \\
\hline 1. & Вінницька & 2649,2 & 2014,2 & 1725,5 & 76,0 & 65,1 & 85,7 \\
\hline 2. & Київська & 2816,2 & 1658,9 & 1353,7 & 58,9 & 48,1 & 81,6 \\
\hline 3. & Кіровоградська & 2458,8 & 2032,3 & 1764,5 & 82,7 & 71,8 & 86,8 \\
\hline 4. & Полтавська & 2875,1 & 2165,4 & 1774,7 & 75,3 & 61,7 & 82,0 \\
\hline 5. & Черкаська & 2091,6 & 1451,0 & 1272,0 & 69,4 & 60,8 & 87,7 \\
\hline \multicolumn{2}{|c|}{ Загалом } & 12890,9 & 9321,8 & 7890,4 & 72,3 & 61,2 & 84,6 \\
\hline
\end{tabular}

Доведено, що гранично допустимий рівень розораності території не повинен перевищувати 40\% [1], а сільськогосподарських угідь - 50\% [2]. Із табл. 3 видно, що показник розораності території тільки по Київській області близький до гранично допустимого, за всіма іншими областями як розораність території, так і розораність сільськогосподарських угідь значно перевищують гранично допустимі рівні. Це свідчить про екстенсивний спосіб використання земель, відповідно склад і співвідношення компонентів сучасних агроландшафтів різко погіршились.

За цих умов важливим завданням у сфері оптимізації структури земельного фонду України в цілому й Лісостепу зокрема, мають стати заходи щодо вилучення з інтенсивного обробітку деградованих малопродуктивних земель, до яких відносяться сільськогосподарські угіддя, що характеризуються низькою родючістю та переведення значної їх частини в природні кормові угіддя.

За останнє десятиліття на території Центрального Лісостепу тенденції до зменшення частки ріллі у загальній площі сільськогосподарських угідь дуже незначні - 4,0 тис.га (0,03\%). Оскільки рілля $\epsilon$ основним дестабілізуючим екологічним фактором, розглянемо більш детально ії динаміку. Найбільше скорочення площі ріллі спостерігається у Київській області - на 13,7 тис.га $(0,11 \%)$. У Вінницькій області цей показник зменшився на 4,4 тис.га $(0,03 \%)$, у Черкаській - на 1,8 тис.га $(0,01 \%)$. У двох областях, навпаки, простежується незначне збільшення площі ріллі. У Кіровоградській області - на 1,4 тис.га $(0,01 \%)$, у Полтавській - на 14,5 тис.га $(0,11 \%)$, при чому збільшення площі орних земель в області пояснюється скороченням площі перелогів (на 41,4 тис.га - 0,32\%). 


\section{3. Лісистість Центрального Лісостепу Украӥни за адміністративними областями станом на 01.01.2016 p.}

\begin{tabular}{|c|c|c|c|c|c|}
\hline \multirow{2}{*}{$\begin{array}{l}\text { № } \\
\Pi / \Pi\end{array}$} & \multirow{2}{*}{$\begin{array}{c}\text { Адміністративна } \\
\text { область }\end{array}$} & \multirow{2}{*}{$\begin{array}{c}\text { Загальна площа, } \\
\text { тис. га }\end{array}$} & \multirow{2}{*}{$\begin{array}{c}\text { Ліси та лісовкриті } \\
\text { площі, тис. га }\end{array}$} & \multicolumn{2}{|c|}{ Лісистість, \% } \\
\hline & & & & фактична & оптимальна \\
\hline 1. & Вінницька & 2649,2 & 380,3 & 14,4 & 16,0 \\
\hline 2. & Київська & 2816,2 & 648,7 & 23,0 & 23,0 \\
\hline 3. & Кіровоградська & 2458,8 & 189,0 & 7,7 & 11,0 \\
\hline 4. & Полтавська & 2875,1 & 286,03 & 9,9 & 15,0 \\
\hline 5. & Черкаська & 2091,6 & 338,6 & 16,2 & 16,0 \\
\hline \multicolumn{2}{|c|}{ Загалом } & 12890,9 & 1842,6 & 14,3 & 17,0 \\
\hline
\end{tabular}

Лісистість території Центрального Лісостепу в середньому становить $14,3 \%$. Найвища лісистість характерна для Київської області - 23,0 \%, найменша для Кіровоградської області - 7,7 \%. Лісистість території Черкаської області становить 16,2 \%, Вінницької - 14,4 \%, Полтавської області 9,9 \% (табл. 3). У Київській та Черкаській областях фактична лісистість відповідає наукового обгрунтованій оптимальній лісистості [8]. В інших областях і центральному Лісостепу загалом, фактична лісистість менша за оптимальну: у Вінницькій області - на 1,6\%, у Кіровоградській - на 3,3\%, у Полтавській області - на 5,1\%. Щодо співвідношення угідь, за яким прийнято оцінювати екологічний стан агроландшафтів, в центральному Лісостепу України становить 1:0,2:0,1 (рілля : сіножаті i пасовища : ліси), при науково обгрунтованих 1:1,6:3,6 [8]. Це свідчить про невідповідність та розбалансування агроландшафту.

Слід зазначити, що в Україні розроблені та впроваджені державні програми щодо удосконалення землекористування, розвитку земельних відносин, оптимізації складу агроландшафтів тощо. Так, згідно $з$ наказом Міністерства аграрної політики України та президії УААН № 26/33 від 03.04.2000 року "Про першочергові заходи щодо удосконалення землекористування", близько 9 млн. га орних земель України до 2015 р. підлягало консервації й вилученню з інтенсивного обробітку. Площа сільськогосподарських угідь центрального Лісостепу України зазнала деяких змін, але вони $є$ абсолютно не суттєвими та кардинально не змінюються. Щодо лісового господарства, то Державною програмою “Ліси України” на період 20022015 pp. було передбачено збільшення лісистості території до науково обгрунтованого рівня - $19 \%$. Виходячи із результатів дослідження, очевидно, що наразі лісистість території має далеко не оптимальні параметри, а заплановане збільшення лісистості не відбулося.

Висновок. У структурі земельного фонду центрального Лісостепу України переважають площі сільськогосподарських угідь - 72,3 \% від загальної площі. Зона дослідження характеризується надзвичайно високим рівнем сільськогосподарської освоєності - 72,3 \% (коливання 58,9-82,7 \%), розораності території - 61,2\% (коливання 48,1-71,8\%), розораності сільськогосподарських угідь - 84,6\% (коливання 81,6-87,7\%). На противагу антропогенно трансформованим компонентам частка лісистості залишається невисокою - 14,3 \%. Структура земельних угідь екологічно розбалансована, співвідношення угідь становить 1:0,2:0,1 (рілля : сіножаті і пасовища : ліси) при науково обгрунтованих $1: 1,6: 3,6$.

Незважаючи на низку розроблених заходів щодо оптимізації структури агроландшафтів та законодавчо закріплених актів на державному рівні, аналіз динаміки структури агроландшафтів за останне десятиліття виявив дуже незначні позитивні зміни. Скорочення площ сільськогосподарських угідь вкрай мала $-0,8 \%$, збільшення площі лісів як екологостабілізуючих угідь становить лише $0,2 \%$.

Таким чином, рівень освоєності та розораності території більшості областей центрального Лісостепу залишається високим. Як наслідок - деградація земель та зниження родючості. За цих умов важливим завданням у сфері оптимізації структури земельного фонду України в цілому й центрального Лісостепу зокрема мають стати більш рішучі заходи щодо вилучення з інтенсивного обробітку деградованих малопродуктивних земель, до яких належать сільськогосподарські угіддя, що характеризуються негативними природними властивостями, низькою родючістю.

Проведений нами аналіз структури та динаміки земельних ресурсів центрального Лісостепу України вказує на відсутність суттєвих позитивних змін у здійсненні екологічної політики держави у сфері управління земельними ресурсами. Екологічна ефективність управління земельними ресурсами та землекористуванням характеризується неефективними управлінськими діями щодо організації використання землі. 


\section{БІБЛІОГРАФІЯ}

1. Булигін С. Ю. Формування екологічно сталих агроландшафтів / С. Ю. Булигін. - К. : Урожай, 2005. - 300 c.

2. Вилучення з інтенсивного обробітку малопродуктивних земель та їхнє раціональне використання : методичні рекомендації / [За ред. В. Ф. Сайка]. - К. : Аграрна наука, 2000. - 39 с.

3. Економіка сільського господарства : Навч. посібник / Збарський В. К., Мацибора В. І., Чалий А. А. та ін.; За ред. В. К. Збарського і В. І. Мацибори. - К. : Каравела, 2010. - 280 с.

4. Міністерство екології та природних ресурсів. Діяльність охоронна. Екологічні паспорти регіонів : режим доступу http://old.menr.gov.ua/index.php/ protection/protection1

5. Національна парадигма сталого розвитку України / За заг. ред. Б. Є. Патона. - К.: Держа-

\section{ANNOTATION}

Slavgorods'ka Ju. V. Modern status and dynamics of changes in land resources of the Central ForestSteppe of Ukraine.

The article considers the current state of use of land resources of the Central Forest-Steppe of Ukraine in the context of administrative regions Vinnytsa, Kyiv, Kirovograd, Poltava, Cherkasy.

Structural distribution of land resources by types of land was analyzed. The Central Forest-Steppe of Ukraine as of 01.01.2016 is 12890,9 thousand hectares. A significant part was occupied by agricultural land $-9321,8$ thousand hectares $(72,3 \%)$, forests and forest cover areas $-1842,63$ thousand hectares $(14,3 \%)$, built-up land - 538,4 thousand hectares $(4.2 \%)$, water (territories covered with surface water) - 579,5 thousand hectares $(4,5 \%)$, other lands $-455,22$ thousand hectares. Features of structural distribution were investigated of agricultural land. The excessive level of agricultural development of the territory is determined $-72,3 \%$, the area's cultivation is $61,2 \%$, agricultural land plots $84,6 \%$. Such indicators significantly exceed the maximum permissible levels, which indicate extensive use of land. It is established that the structure of вна установа "Інститут економіки природокористування та сталого розвитку Національної академії наук України", 2012. - 72 с.

6. Основи стійкого розвитку: навчальний посібник / За заг. ред. д. е.н., проф. Л. Г. Мельника. - Суми: ВТД «Університетська книга», 2005. $654 \mathrm{c}$.

7. Третяк А. М. Екологія землекористування: теоретико-методологічні основи формування та адміністрування: монографія / А. М. Третяк. Херсон : ФОП Грінь Д. С., 2012. - 440 с.

8. Фурдичко O.I. Методологія управління агроландшафтами лісомеліоративними методами [Науково-методичне забезпечення] / О. I. Фурдичко, А. П. Стадник. - К. : Аграрна наука, 2010. $-60 \mathrm{c}$.

land is ecologically unbalanced.

The period of 2005-2016 was analyzed a dynamics of land fund changes. Thus, the area of land has undergone some changes, but they are completely unimportant and do not radically change. The reduction of agricultural land is extremely low $(0,8 \%)$, the increase in the forest area as an ecolabelling lands is only $0,2 \%$. The decrease in the share of arable land in the total area of agricultural land is very small $-4,0$ thousand hectares $(0,03 \%)$. The reduction of arable land was observed in Kyiv region - by 13,7 thousand hectares, in Vinnyts'a - by 4,4 thousand hectares, Cherkasy region - by 1,8 thousand hectares. There is a slight increase in the area of arable land in Kirovograd region - by 1,4 thousand hectares and in Poltava region - by 14,5 thousand hectares.

We offered measures to optimize the use of land resources. In particular, an important task in the field of optimization of the structure of the land fund should be measures for the removal of intensive cultivation of degraded, low productive land.

Key words: land resources, dynamics of land fund changes, optimization of agrolandscapes. 